\title{
Synergized Plant Leave Extracts as Substitute to Toxic Additives in Alkyd Resin Primer for Corrosion Inhibition of Steel
}

\author{
Sodiya Ezekiel Folorunso", Dawodu Folasegun Anthony, Oyedele Adebayo Abidemi \\ Chemistry Department, Faculty of Science, University of Ibadan, Ibadan, Nigeria \\ Email address: \\ sodiyaezekiel@gmail.com (E. F. Sodiya), fadawodu@yahoo.com (F. A. Dawodu), adebayo.oyedele@gmail.com (A. A. Oyedele) \\ ${ }^{*}$ Corresponding author
}

\section{To cite this article:}

Sodiya Ezekiel Folorunso, Dawodu Folasegun Anthony, Oyedele Adebayo Abidemi. Synergized Plant Leave Extracts as Substitute to Toxic Additives in Alkyd Resin Primer for Corrosion Inhibition of Steel. American Journal of Applied Chemistry. Vol. 4, No. 3, 2016 , pp. 97-103. doi: $10.11648 /$ j.ajac.20160403.15

Received: April 22, 2016; Accepted: May 4, 2016; Published: May 23, 2016

\begin{abstract}
Inhibition of steel corrosion by synergized leave extracts of Sida acuta and Jatropha curcas as additives substitute to synthetic compounds in Alkyd based Primer coats was investigated in $1.0 \mathrm{M} \mathrm{HCl} \mathrm{using} \mathrm{the} \mathrm{gasometric} \mathrm{technique} \mathrm{at} 30^{\circ} \mathrm{C}$ and $50^{\circ} \mathrm{C}$. Results obtained showed that the extract alternative effectively inhibited corrosion of degalvanised steel more than the synthetic chemical. This was confirmed by optimum inhibition efficiency of $93 \%$ to $90 \%$ corrosion rate $0.202 \mathrm{~cm}^{3} / \mathrm{hr}$ to $0.337 \mathrm{~cm}^{3} / \mathrm{hr}$ of the extract to the synthetic compound. Activation energy and Energy of adsorption decrease with time. Fourier transform infra red analysis confirmed the presence of $\mathrm{C}=\mathrm{O}$ of ester by the presence of $\mathrm{C}-\mathrm{O}$ functional band at $1094 \mathrm{~cm}^{-1}$. Surface morphology of the steel with the synergized were studied with Scanning electron microscope (SEM) and Electron dispersive X-ray spectroscopy (EDX) which revealed the protection of the internal grains of the metal from dissolution into corrodent provided by the adsorbed film the extract.
\end{abstract}

Keywords: Synergized Extract, Jatropha curas, Sida acuta, Deglavanised Steel, Alkyd-Extract Primer, Alkyd Zn-primer

\section{Introduction}

Corrosion resistance of pure metal is usually better than those containing impurities or some amount of other elements. However pure metal are expensive and its physical state may not fit into the required strength of some technical. [1] Therefore is need to maintain those containing impurities or some amount of other element either not fully purified or intentionally embedded as alloy constituents. Refined metals are unstable. They tend to return to their combined state with other elements or compounds present in their environments. In so doing they lose aesthetics and technical value. This reversal reaction is corrosion which has been general termed rust. This process is of economic disadvantage to the manufacturing and construction industries. Rust prevention by selective maintenance coating materials based on corrosion phenomena to be addressed. The corrosion prevention required dictates the coating formulations in consonance with corrosion phenomenon. Protective coatings consist of breaking external circuit or redox reaction by using an insulation barrier or coating which adhered to the iron surface. The use of coating materials will impede or resist electrolytically the corrosion current initiated by corrosive agent present in the substrate environment.

Coating of metal with primers are one of the method adopted to create corrosion barriers mainly used on iron steel works to prevent corrosion or reduce the already existing corrosion process to tolerable level. [2] Primers could be produced through resin that active as binding medium for other components of the solution. Resins are polymeric compounds in various forms which could be epoxy, alkyd or 2 pack polyurethane, depending on the polymerization process.

Primers are classified by the major pigments used as the polymeric binders. It could be metallic, such as Tin, Aluminium, Zinc, Silver or Gold. It could be produced through the mixing of various chemical compound such as Iron oxide, Zinc chromate $\mathrm{ZnCrO}_{4}$ or Zincphosphate 
$\left(\mathrm{Zn}_{3}\left(\mathrm{PO}_{4}\right)_{2}\right.$. The inhibitive compounds may be incorporated into the primer recipe singly or combined depending on the percent active required of the primer. Zincphosphate whitish in colour and non-toxic are used for steel protection by supplies of phosphate ions for phospating of the steel surface at damp conditions Zinc chromate when used impact yellow into the medium as colouring advantage to required inhibitive effect but it is carcinogenic and toxic. Both zinc compounds are compatible with various media by which mechanism of their corrosion inhibition is effective. [3]

Extracts from natural plants have been confirmed to inhibit corrosion of metals. Investigations have continued of confirmation of some local plants as replacement for synthesized organic inhibitors. [4]

Sida acuta It is from the family Malvaceae and a dicot genus of about 200 species originated from Central America and occurring all over the warm tropics. It is used to treat snake bite in Gambia and Colombia. It is a common weed distributed in most regions of the world. Its leaves and stems in the rural areas in Nigeria have been used to treat whitlow. [7] The leaves are however deemed to have some cleansing property for bruised in water, they are used to scrub the body and a wash for dogs, goats etc for scab and parasitic skin diseases. The leaves are sometimes with other local medicine taken medicinally cooked with rice and eaten with some incantations as bullet neutralizer from gunshot in Africa. In Central America, the plant has been used for treatment of fever at the level of colds and headache symptoms. It can also be used to treat asthma, renal inflammation, ulcer and intestinal worms. [8]

Jatropha curcas is a plant that is easily propagated plant by stem and seed. It is often used to demarcate graves and boundaries of fields or farmlands. The stem is used as support for leguminous crops in some West African countries such as Gabon. The dried fruits are being powdered and taken along with food to ease out excessive fat through diarrhea and vomiting. [5]

This research investigate the use of synergized plant leave extracts in comparison with synthesized toxic compounds in primers as inhibitive component of primer for coating steel.

\section{Materials and Method}

\subsection{Metal Elemental Composition Analysis}

The compositional analysis was carried out on the degalvanized metal samples used for this study by Metal Spectrometer Analyser of Model ARL Quanbo Desk OTD 226 (Optical emission).

Table 1. Results of Percentage Elemental Composition of Degalvanized steel Pipe.

\begin{tabular}{|c|c|c|c|c|c|c|c|c|c|c|c|c|c|}
\hline Elements & C & Co & Mo & $\mathbf{V}$ & $\mathbf{F e}$ & $\mathbf{S i}$ & Mn & $\mathbf{N b}$ & $\mathrm{Cr}$ & $\mathbf{N i}$ & $\mathrm{Cu}$ & $\mathbf{S}$ & $\mathbf{P}$ \\
\hline$\%$ & 0.1551 & 0.0463 & 0.0106 & 0.0169 & 98.42 & 0.2378 & 0.5571 & 0.0823 & 0.0626 & 0.1499 & 0.0792 & 0.0445 & 0.0280 \\
\hline
\end{tabular}

\subsection{Metal Sample Preparations}

A galvanized steel pipe of $3.0 \mathrm{~mm}$ thickness was sliced into $18 \mathrm{~mm}$ x $9 \mathrm{~mm}$ by saw on lathe machine. The galvanized coupons were degalvanised.

\subsection{Degalvanization}

The galvanized samples was submerged in $10 \%$ sulphur acid solution of Analar grade to remove the zinc coat. The reaction was stop by dipping in distilled water and then dried in the oven. The surface was polished using emery paper 400 grades and further smoothened with 800 emery paper grade. $0.26 \mathrm{~mm}$ was removed from the surfaces through to this process. The coupons thickness were determined with Mitutoyo analog micrometer screw gauge while other dimensions were also confirmed using Mitutoyo digital venier gauge of 2 decimal place make. Surface treatment of the coupons was done by degreasing in ethanol and dried with acetone. They were then stored in moisture free desiccators to prevent rusting or contamination prior to use. [9]

\subsection{Plant Leave Extraction}

Plant leaves of Jatropha curcas and Sida acuta were air dried and ground into powder. $10 \mathrm{~g}$ was soaked in $100 \mathrm{ml}$ of ethanol. $5 \mathrm{~g}$ each of the plant leaves were weighed and also mixed in $250 \mathrm{ml}$ conical flask containing $100 \mathrm{ml}$ ethanol. The corked conical flask containing the substance was left to stand for 48 hours with occasional shakings. [10] The mixture was filtered and residue thoroughly washed with ethanol. The solvent was recovered by concentration of the extract using rotary evaporator. It was evaporated to oily extract on water at $75^{\circ} \mathrm{C}$ to finally expel the leftover ethanol. [11]

\subsection{Production of Primers}

Three Primed coupons were produced using the recipe in Table 2. The recipe constituents were dissolved in toluene. Thesame weight of the extract and zinc compounds (zincphosphate and zinc chromate) were used as additives in the first and second primer samples. The extract concentration was doubled as indicated in Table 2 to obtain the third primer sample.

\subsection{Coating of Degalvanised Coupons with Primer}

$20 \mathrm{ml}$ from each primer was introduced into a $50 \mathrm{ml}$ beaker. A degalvanized steel sample of same $18 \mathrm{~mm}$ by $9 \mathrm{~mm}$ was submerged in the primer for 30 minutes. It was removed and air dried for 3 hours. The submerge and removal for drying process was repeated twice to attain the original galvanized steel thickness of $3.1 \mathrm{~mm}$ from $2.9 \mathrm{~mm}$ of the sample. It was finally left to air dried for 48 hours. 
Table 2. Recipe for Alkyd and Extract base Primers.

\begin{tabular}{llll}
\hline & Alkyd-base components \%wt(g) & Conventional Primer \%wt(g) & Extract-Primer \%wt(g) \\
\hline Alkyd resin & 52.36 & 52.36 & 52.36 \\
Zincdichromate & 2.12 & & - \\
Zincphosphate & 2.14 & & - \\
Synergized JC \& SA & - & 4.26 & 8.52 \\
Talc $\left(\mathrm{MgSi}_{2} \mathrm{O}_{3}\right)$ & 9.68 & 9.68 & 9.68 \\
$\mathrm{CaCO}_{3}$ (precipitated) & 8.40 & 8.40 & 8.40 \\
Toluene & 23.12 & 23.12 & 23.12 \\
Antiskinning agent & 0.23 & 0.23 & 0.23 \\
Drier & 1.95 & 1.95 & 1.95 \\
\hline
\end{tabular}

\subsection{Gasometric Procedure}

$50 \mathrm{ml}$ of $1.0 \mathrm{M} \mathrm{HCl}$ acid was introduced into Mylius cell. The coupon was dropped into the corrodent $(\mathrm{HCl})$ and corked airtight with vaseline. The unit was placed into a thermostatic bath. [12] The released hydrogen gas by downward displacement of water was noted hourly on the calibrated tube (inverted burrette) at $30^{\circ} \mathrm{C}$ and $50^{\circ} \mathrm{C}$ respectively. The experiment was repeated with the coupon coated with alkyd zinc additive primer, alkyd-plant extract primer and alkyplant extract primer of doubled extract weight dropped into $1.0 \mathrm{M} \mathrm{HCl}$ solution. Schematic diagram of the experiment as described elsewhere. [13]

\subsection{Inhibition Efficiency}

The Inhibition Efficiency (I.E.) for the plant extracts was deduced by equation [14].

$$
\% \text { I.E. }=\left\{1-\left(\mathrm{V}_{\text {in }} / \mathrm{V}_{\text {uni }}\right)\right\} \times 100
$$

Where $\mathrm{V}_{\text {in }}=$ Volume of hydrogen evolved for inhibited solution and

$\mathrm{V}_{\text {uni }}=$ Volume of hydrogen evolved for uninhibited solution both at time $\mathrm{t}$.

$$
\text { Surfaced coverage } \theta=\text { I. E./100 }
$$

\subsection{Corrosion Rate $\mathrm{cm}^{3}$ Per Hour}

$$
\text { From } \mathrm{R} \alpha \mathrm{d} \Delta \mathrm{W}_{\mathrm{m}} / \mathrm{dt} \alpha \mathrm{d} \Delta \mathrm{V}_{\mathrm{H} 2} / \mathrm{dt}
$$

volume of hydrogen gas release in dependent on time $t$ was deduced using

polynomial regression analysis

$$
\mathrm{V}_{\text {in }}=\mathrm{c} \pm \mathrm{bt} \pm \mathrm{at}^{2}[15] \text { Ajayi et al }
$$

Differentiating equation (4) resulted to $\mathrm{R}=\mathrm{dv} / \mathrm{dt}=\mathrm{b}+2 \mathrm{at}$ which could be

$$
\text { rearranged as } \mathrm{R}=2 \mathrm{at} \pm \mathrm{b}
$$

For the degalvanised steel in alkyd zinc and alkyd-extract primer coated steels in $\mathrm{HCl}$ acid, equations (4) and (5) are employed to obtain expressions for calculation corrosion rate R. Where $\mathrm{x}=\mathrm{t}[11]$

Degalvanised steel $\mathrm{y}=0.059 \mathrm{x}^{2}+1.588 \mathrm{x}+0.135 ; \mathrm{dv} / \mathrm{dt}=$ $0.118 x+1.588$
Alkyd-Zinc compound $\mathrm{y}=0.004 \mathrm{x}^{2}+0.138 \mathrm{x}+0.257$; $\mathrm{dv} / \mathrm{dt}=0.008 \mathrm{x}+0.138$

Alkyd Extract $\mathrm{y}=0.008 \mathrm{x}^{2}+0.042 \mathrm{x}+0.169 ; \mathrm{dv} / \mathrm{dt}=$ $0.016 \mathrm{x}+0.042$

\section{Results and Discussions}

The plant extracts imparted green colouration while zinc chromate imparted yellow. Higher constituent of the zinc base additives in the Alkyd Primer is due to increase in the main binder. Talc and Carbonate were added as extenders to improve adhesion, Their high constituents in the primer was to maintain its viscosity due to oily contribution from the extract as the weight content was increased compared with the dried nature of zinc compounds.

\subsection{Effectiveness of Plant Leave Extract over Conventional Synthetics Compounds Additives as Inhibitors in Polyurethane Base Primer}

The phytoconstituents in the plant extracts contains heteroatoms which are sites through which extracts got adsorped to the surface of the metal for corrosion inhibition to be effected.

The conventional additives are ionic compounds. The chromate ion $\left(\mathrm{CrO}_{4}\right)^{2-}$ in per mole of Zinc chromate $\left(\mathrm{ZnCrO}_{4}\right)$ and the phosphate ion $\left(\mathrm{PO}_{4}\right)_{2}{ }^{3-}$ in per mole of Zincphosphate $\mathrm{Zn}_{3}\left(\mathrm{PO}_{4}\right)_{2}$ were $65 \%$ and $66 \%$ respectively. They were the 'percent active' per mole of the Zinc compounds that primarily adsorbed unto the metals. $65 \% \mathrm{x}$ $1.95 \mathrm{~g}=1.27$, which implies that $1.27 \mathrm{~g}$ out of $1.95 \mathrm{~g}$ Zinc chromate $\left(\mathrm{ZnCrO}_{4}\right)$ was responsible for the adsorption. $66 \%$ $x 1.99 \mathrm{~g}=1.31$, which implies that $1.31 \mathrm{~g}$ out of the $1.99 \mathrm{~g}$ Zincphosphate $\mathrm{Zn}_{3}\left(\mathrm{PO}_{4}\right)_{2}$ was responsible for the same process. According to Raimi et al., 2014, [16] the total phytoconstituents in SA was $5.82 \%$. While Harry-Asobara et al., 2014 [17] reported total of $1.28 \%$ in JC. Hence mixture of JC with SA carried out in ratio $4: 1$ in order to have = $(4 \times 1.28+1 \times 5.82)=10.94 \%$. Therefore $10.94 \% \times 3.94=0.43$, which implies $0.43 \mathrm{~g}$ out of $3.94 \mathrm{~g}$ of the extract was responsible for the adsorption.

Inferably, $21.88 \%$ of extracts as the 'percent active' was responsible for the same adsorption process at double concentration considered for the synergized extract. Therefore $7.88 \mathrm{~g}$ x $21.88 \%=1.72$. This implies $1.72 \mathrm{~g}$ out of 
$7.88 \mathrm{~g}$ of the extract was responsible for the adsorption. This was less to the combined weight of $(1.27+1.31)=2.58 \mathrm{~g}$ contributed by the chemical additives in the primer but gave improved inhibition efficiency over conventional additives. The increase in the inhibition performance of the extract may not have been attributed only to increase in extract concentration due to the doubling of the equivalent weight of the extract but also to the synergistic effect of the two extracts. The esterification product of saponin constituents of two synergized plant extracts containing $\mathrm{OH}$ and $\mathrm{COOH}$ in the acidic medium may have contributed to the increase in the inhibition performance.

The IR spectrum of synergized plant leaves extract before use as inhibitor was revealed in Figure 1. The broad but weak band at $3381 \mathrm{~cm}^{-1}$ depicted the presence of O-H of carboxylic acid. The stretching vibration at $3012 \mathrm{~cm}^{-1}$ was for $\mathrm{C}-\mathrm{H}$ of aromatic while that of $2924 \mathrm{~cm}^{-1}$ and weak band at $2853 \mathrm{~cm}^{-1}$ were due to presence of $\mathrm{C}-\mathrm{H}$ of aliphatic compound. The strong band at $1744 \mathrm{~cm}^{-1}$ was ascribed to stretching vibrational frequency of $\mathrm{C}=\mathrm{O}$ of esters and lactones. This was absent in the individual plant extracts that were used for synergism to improve the inhibitory potential of the extract. The weak band at $1644 \mathrm{~cm}^{-1}$ was assigned to imines and oximes moieties. The weak bands at 1463 and $1376 \mathrm{~cm}^{-1}$ were assigned to the presence of $\mathrm{N}=\mathrm{O}$ of Nitro group. The weak bands at $1240 \mathrm{~cm}^{-1}, 1162 \mathrm{~cm}^{-1}$ and $1094 \mathrm{~cm}^{-1}$ represented C-O stretching vibrational band of alcohol, ethers and esters. Weak bands at $724 \mathrm{~cm}^{-1}$ and $661 \mathrm{~cm}^{-1}$ were assigned to the bending vibrational mode of amines. The presence of $\mathrm{C}=\mathrm{O}$ of ester was further confirmed by the presence of C-O functional band at $1094 \mathrm{~cm}^{-1}$.

There could also have been reactions between the Alkyd resin with synergized extract. These contributions may have therefore created more effectiveness than individual secondary metabolites, taking into consideration that resin and phytoconstituents were of organic origin.

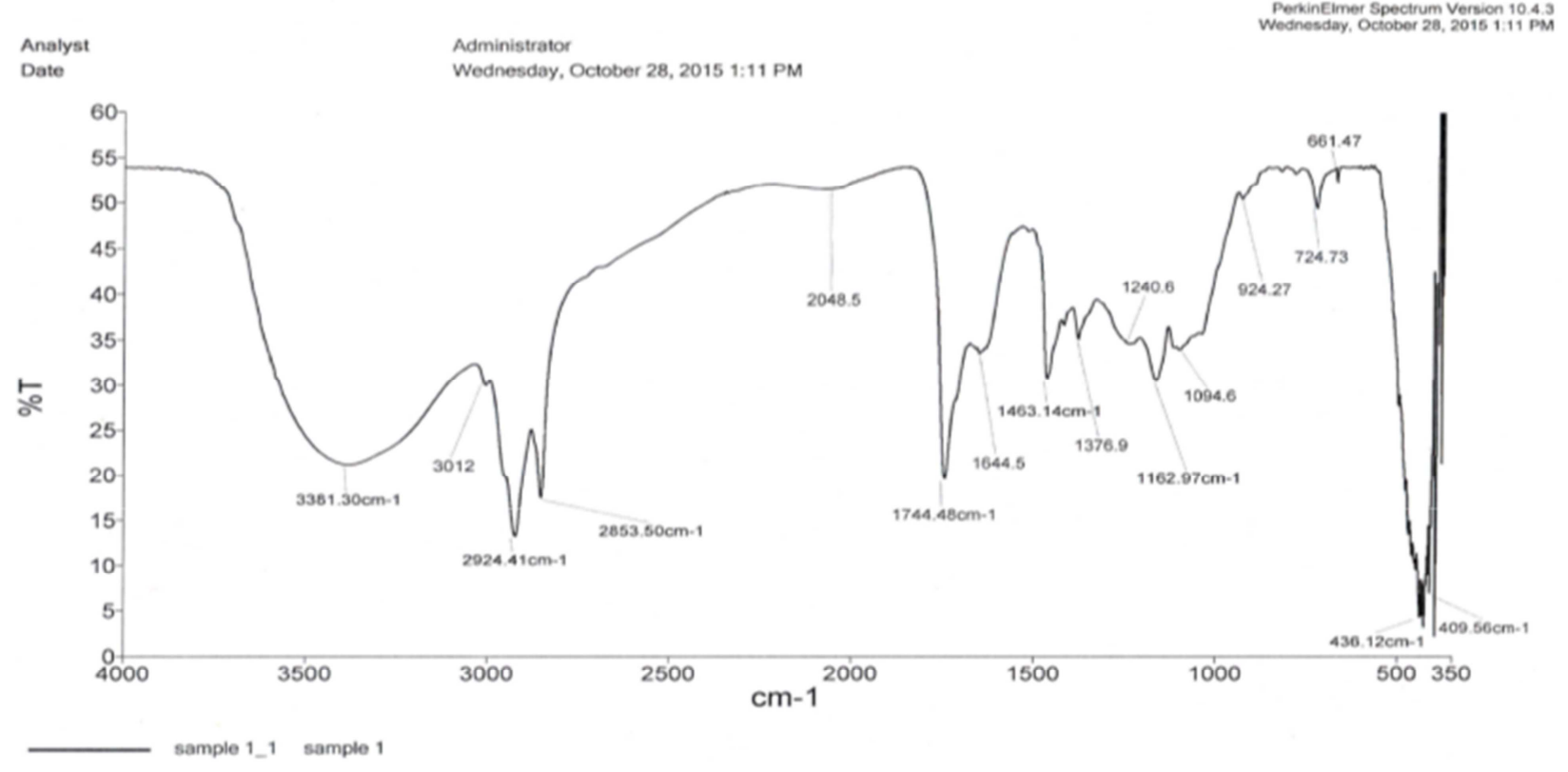

Figure 1. IR Spectrum of synergized Jatropha curcas with Sida acuta plants leave extract.

\subsection{Effectiveness at Equivalent Weight of Extracts and Zinc Compounds}

In Figure 2, $1.0 \mathrm{M} \mathrm{HCl}$ at $30^{\circ} \mathrm{C}$, degalvanised steel evolved hydrogen gas of $16.8 \mathrm{~cm}^{3}$ within 8 hours, compared with Alkyd $\mathrm{Zn}$ compound-primer that gave $1.6 \mathrm{~cm}^{3}$ and Alkyd Extract primer that gave $1.1 \mathrm{~cm}^{3}$ within the same time range at equivalent weight to the Zinc compound with effective weight contribution of $4.26 \mathrm{~g}$.

In Figure 6 , corrosion rate at $30^{\circ} \mathrm{C}$ within 8 hours of degalvanised steel ranges from 1.647 to $2.06 \mathrm{~cm}^{-3}$ per hour, Alkyd Zinc compound ranges from 0.281 to $0.337 \mathrm{~cm}^{-3}$ per hour, Alkyd-Extract ranges from 0.282 to $0.275 \mathrm{~cm}^{-3}$ per hour. The order corrosion rate of the coated materials in $1.0 \mathrm{M} \mathrm{HCl}$ is of the order Alkyd-Extract $>$ Alkyd-Zn. The inhibition efficiency of Alkyd-Zn 76.5\% > Alkyd-Extract $64.7 \%$ at the same weight substitution and the rate of corrosion was in the same order of Alkyd-Zn $>$ Alkyd-Extract.

The rate of corrosion of the same coated materials in the same media at $50^{\circ} \mathrm{C}$ is higher but with corresponding reduction of Inhibition efficiency due to temperature rise as indicated in Figure 7.

\subsection{Effectiveness at Double of Extracts to Zinc Compounds}

Doubling the weight of extract to $8.52 \mathrm{~g}$ at $30^{\circ} \mathrm{C}$ by $8^{\text {th }}$ hour with effective contributory weight of $1.86 \mathrm{~g}$, the order of Inhibition efficiency is Alkyd-Extract $88.2 \%>$ Alkyd-Zn $76.5 \%$. The percent active inhibitor of the extract was $20.88 \%$ while that of zinc compounds are $65 \%$. Primers containing plant extracts were more effective than conventional synthetic chemicals. The degree of effectiveness of covered surface of the steel by the primer material is in the same order of the inhibition efficiency. 


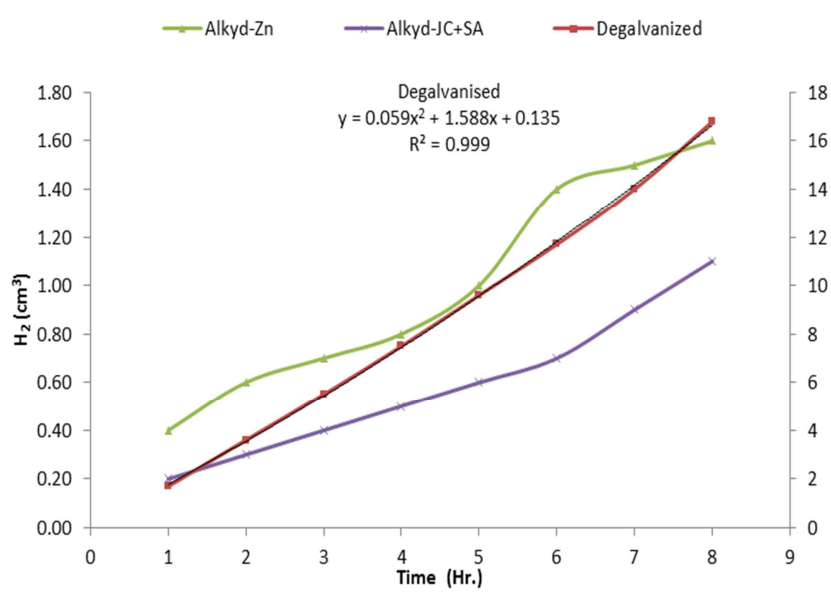

Figure 2. Graph of Hydrogen gas evolved against time (hr) for AlkydExtract and Alkyd-Zinc compound on degalvanised steel in $1.0 \mathrm{M} \mathrm{HCl} \mathrm{at}$ $30^{\circ} \mathrm{C}$.

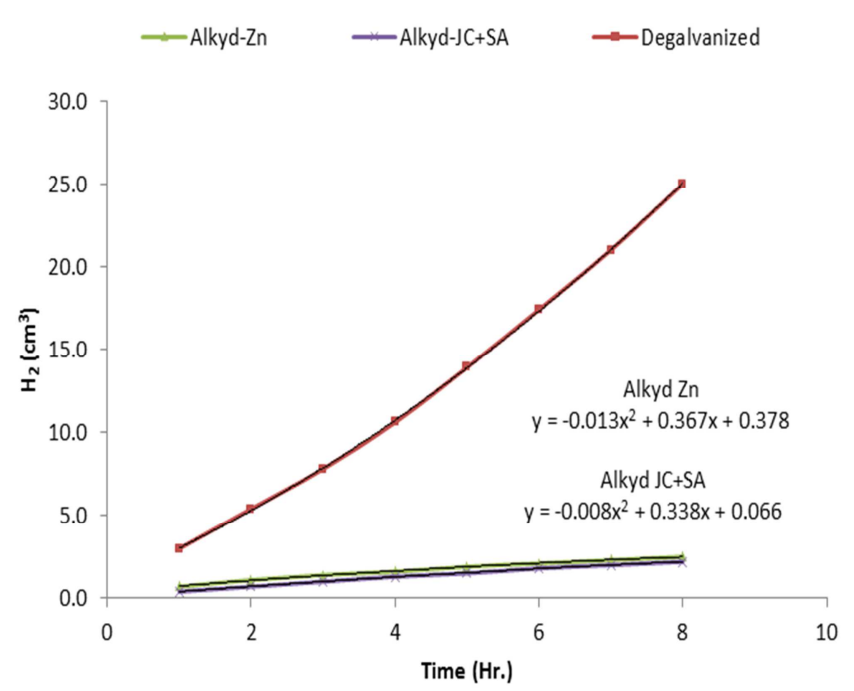

Figure 3. Graph of Hydrogen gas evolved against time (hr) for AlkydExtract and Alkyd-Zinc compound on degalvanised steel in $1.0 \mathrm{M} \mathrm{HCl} \mathrm{at}$ $50^{\circ} \mathrm{C}$.

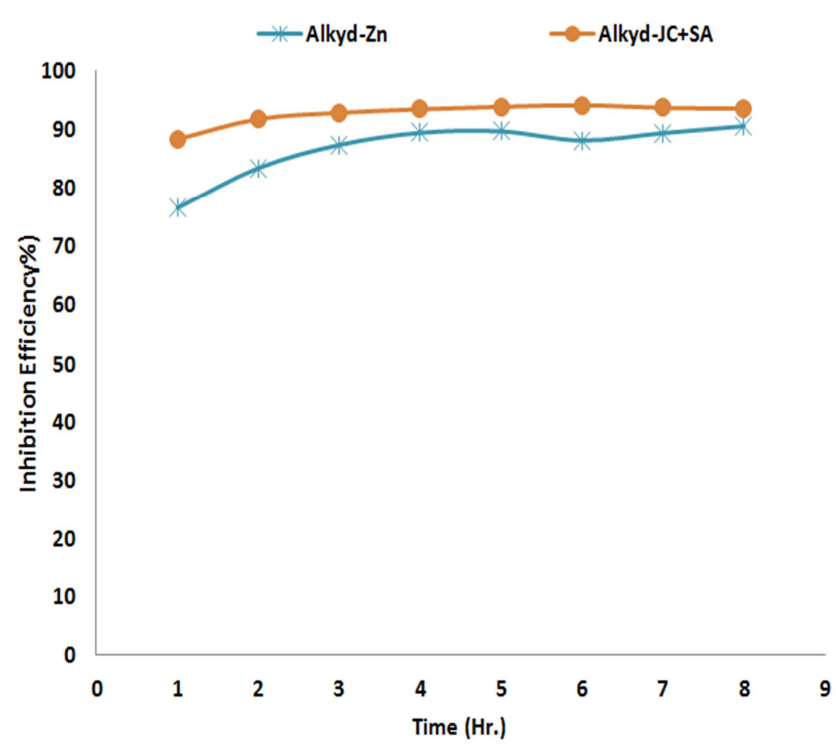

Figure 4. Graph of Inhibition Efficiency against time (hr) for Alkyd-Extract and Alkyd-Zinc compound on degalvanised steel in $1.0 \mathrm{M} \mathrm{HCl} \mathrm{at} 30^{\circ} \mathrm{C}$.

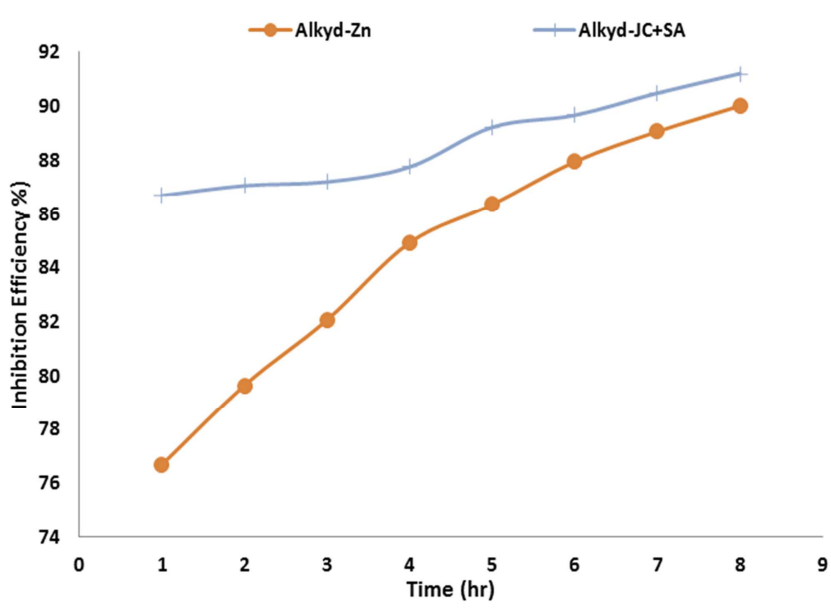

Figure 5. Graph of Inhibition Efficiency against time (hr) for Alkyd-Extract and Alkyd-Zinc compound on Degalvanised steel in $1.0 \mathrm{M} \mathrm{HCl} \mathrm{at} 50^{\circ} \mathrm{C}$.

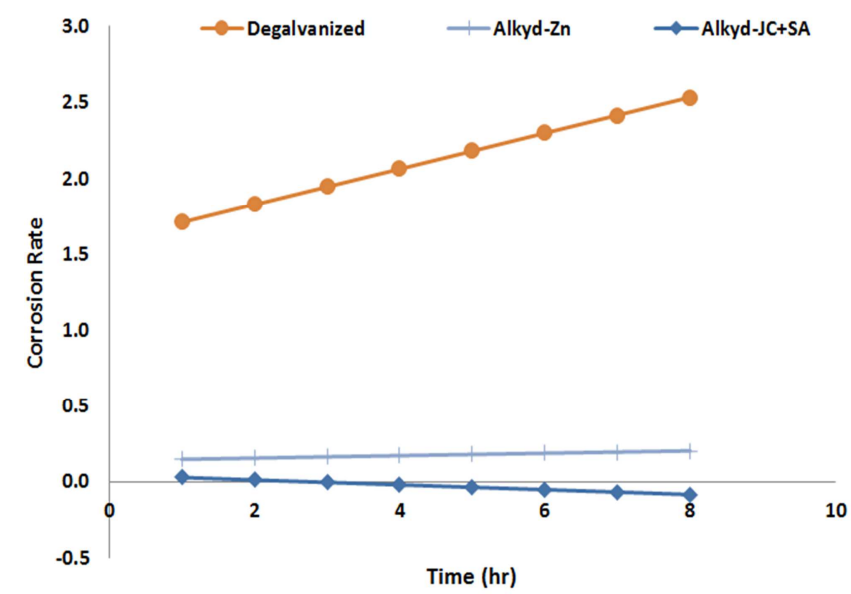

Figure 6. Graph of Corrosion rate $\mathrm{cm}^{-3}$ per hr against time (hr) for AlkydExtract and Alkyd-Zinc compound on Degalvanised steel in $1.0 \mathrm{M} \mathrm{HCl} \mathrm{at}$ $30^{\circ} \mathrm{C}$.

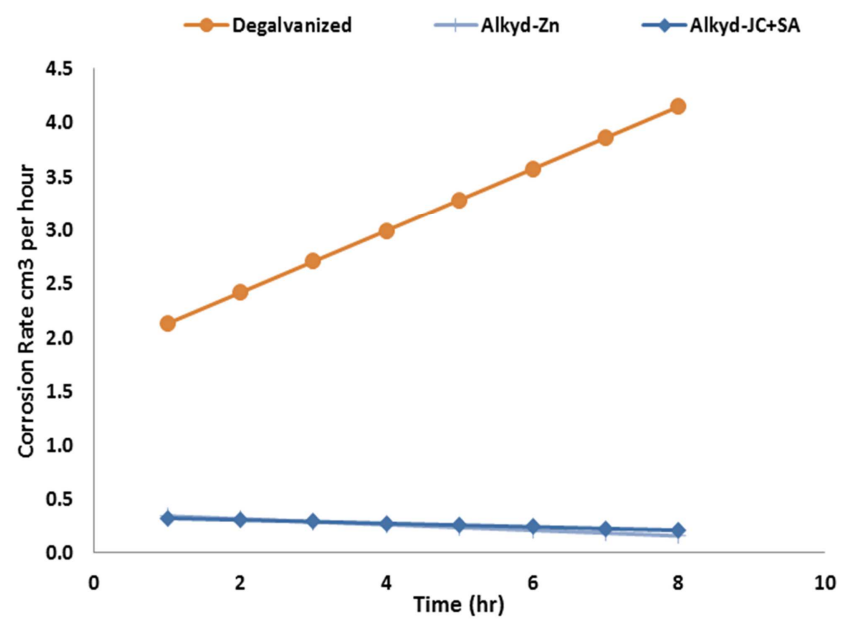

Figure 7. Graph of Corrosion rate $\mathrm{cm}^{-3}$ per hr against time (hr) for AlkydExtract and Alkyd-Zinc compound on Degalvanised steel in $1.0 \mathrm{M} \mathrm{HCl}$ at $50^{\circ} \mathrm{C}$.

\subsection{Surface Morphological Analysis}

SEM image in Figure 8 shows the proctection provided by Synergized plant extract with minimal depletion of material 
from the sample surface. The adsorption of the plant extract created inertness of the alloy to the acidic solution thereby reduced the depreciation rate of the material. Prominent iron peak of 56.66\%was indicated in Figure 9 EDX spectrum, carbon at $18.27 \%$ indicated presence of extract that inhibited the corrosion and $20.08 \%$ oxygen still indicated that some level of corrosion reaction was present.

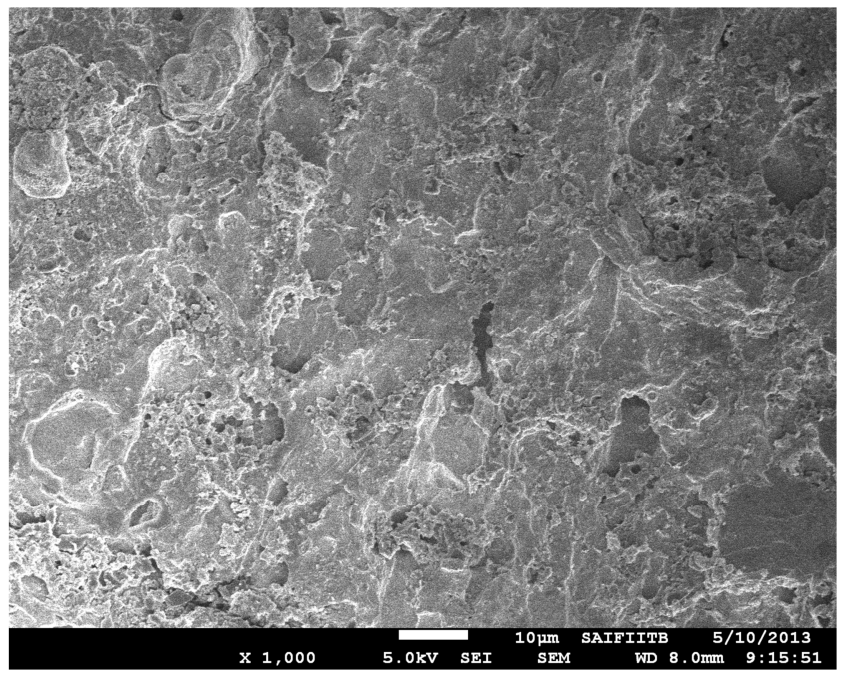

Figure 8. SEM image of protected Degalvanized steel pipe in Synergized extract.

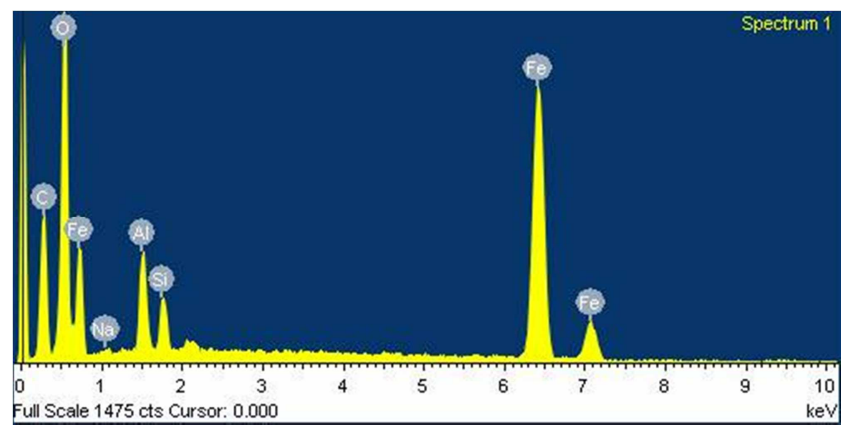

Figure 9. EDX spectrumof protected Degalvanized steel pipe in Synergized extract.

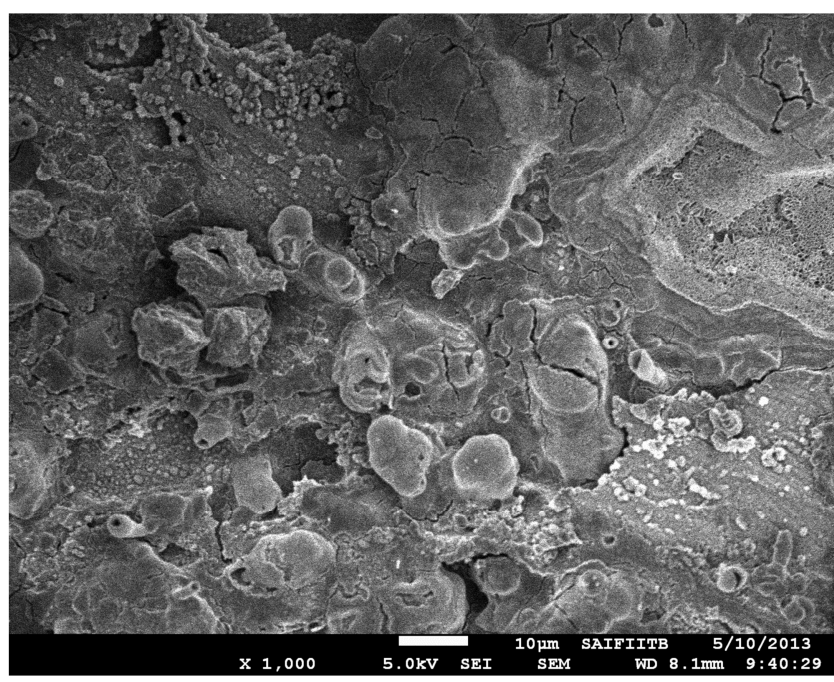

Figure 10. SEM image of Degalvanized steel pipe.

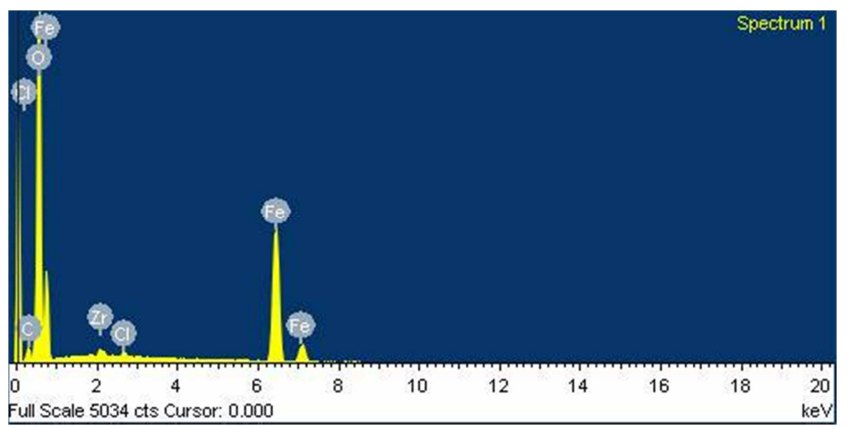

Figure 11. EDX spectrum of Degalvanized steel pipe.

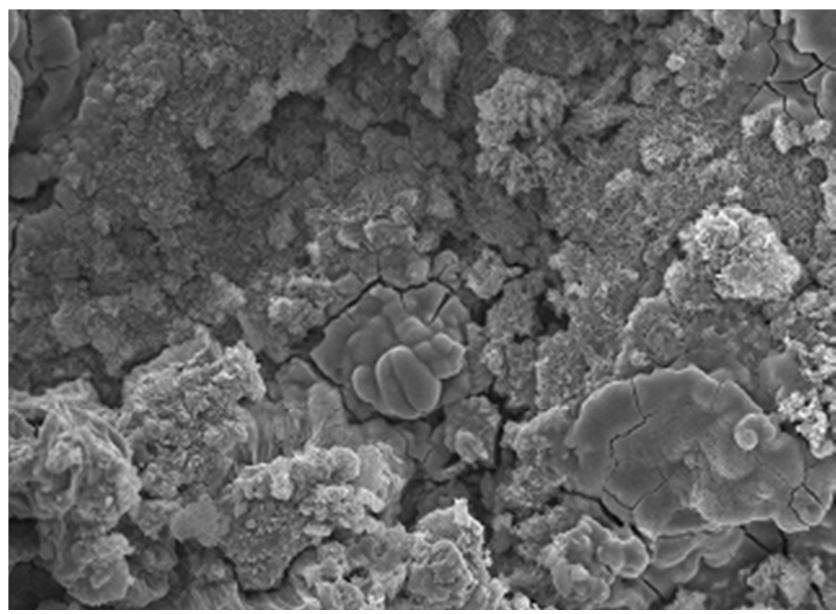

Figure 12. SEM image of Degalvanized steel pipe in $1.0 \mathrm{M} \mathrm{HCl}$ (Control).

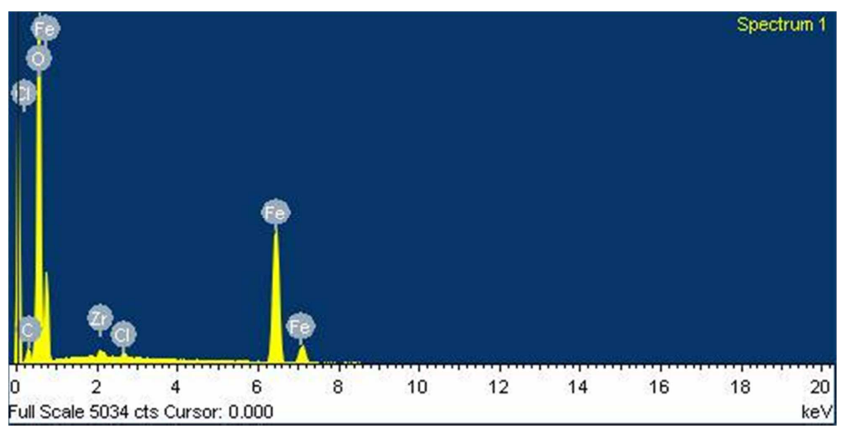

Figure 13. EDX spectrum of Degalvanized steel pipe in $1.0 \mathrm{M} \mathrm{HCl}$ (Control).

SEM image in Figure 10 shows the microstructural arrangement of constituent of steel after been degalvanised containing matrix $\alpha$-Fe phase also known as ferrite and the pearlite $\mathrm{Fe}_{-}-\mathrm{Fe}_{3} \mathrm{C}$ (dark). Other intermetallic phases such as $\mathrm{Fe}-\mathrm{Cu}$ (blue), the $\mathrm{Al}-\mathrm{Fe}$ phase and $\mathrm{Mn}-\mathrm{Fe}-\mathrm{Si}$ are present. Figure 11 EDX spectrum High value of $84.08 \%$ of Fe, $4.02 \%$ Carbon, $11.90 \%$ oxygen is an indication of corrosion processes occuring with moistened air in the enviroment.

The developed strain and stress in the material as a result of aggressive environment from hydrochloric acid produces pathway that aided corrosion. The internal structure of the sample immersed in acid revealed irregular arrangement of grains due to acid effect. The surface of steel metal is characterized by patches of corrosion products. It has made much of $\alpha$-Fe phase to dissolve in to the acid solution. SEM image in Figure 12 shows the deppreciating effect the steel 
surface in $\mathrm{HCl}$ acid as erosion of the ferrite phase from the surface to expose pearlite beneath. Figure 13 EDX spectrum. Promient Iron peak with that of other impuirities such as zirconium with oxygen and carbon. Low value of $61.49 \% \mathrm{Fe}$ and $33.38 \%$ oxygen shows high activities of corrosion on steel by the acid without extract.

\section{Conclusion}

The primer made with 20.88 percent active of extract is more effective than the primer with 65 per cent active of primer made with Zinc compounds. Corrosion rate at $30^{\circ} \mathrm{C}$ at 8th hour in $1.0 \mathrm{M} \mathrm{HCl}$ of Alkyd-Zn was $0.202 \mathrm{~cm}^{-3}$ per hour and Alkyd-Extract $0.026 \mathrm{~cm}^{-3}$ per hour. Correspondingly, the Inhibition efficiency of Alkyd-Zn was $90.47 \%$ and for Alkyd-Extract was $93.22 \%$.

The introduction of Synergized leave extracts of Jatropha curcas and Sida acuta to replace the synthetic inhibitors as additives will reduced the corrosion rate of mild steel. Adsorbed leave extracts provided protection for reduction in the dissolution or precipitation of metal constituents into corrodent. It is characterized with the cloudy oxide film that protected the metal constituent phases of ferrite and pearlite from degenerating. The extracts thereby provided inhibitory activity that induced the reduction in corrosion rate of coupons in the acidic environment.

The replacement of synergized leave extract with the synthetic inhibitors as additives in primers will eliminate exposure to toxic hazards. The synergized extracts could be used as substitute to conventional $\mathrm{Zn}$ primer as coat for steel. A more effective cathodic protection of steel is also achieved with Alkyd Primers containing synergized plant extract.

\section{Acknowledgements}

1) Covenant University, Ota, Nigeria for the equipment and required facilities provided for part of this work.

2) Heritage Coatings \& Allied Chemical Products, Ibadan, Nigeria

\section{References}

[1] Mars G. Fontana 1987, Corrosion Engineering. McGraw-Hill International 3rd edition. Material science and engineering series.

[2] Morgans W. M. 1990. Outlines of Paint Technology. Edward Arnold, A division of Hooder and Stoughton London. ISBN 085264-308 X.
[3] Barraclough J. and Harrison J. B. 1965. New leadless anticorrosive primers, JOCCA 48, 897.

[4] Ekpe, U. J., Ebenso, E. E., Ibok, U. J., (1994) Inhibitory action of Azadirachta indica leaves extract on corrosion of mild steel in tetraoxosulphate (vi) acid dissolution of metals. J. W Afri. Sci Assoc. 37, 13-30.

[5] Loto, C. A., (1998); The Effect of Bitterleaf Extracts on Corrosion of Mild Steel in $0.5 \mathrm{M} \mathrm{HCl}$ and $\mathrm{H} 2 \mathrm{SO} 4$ Solutions, Nigeria Corrosion Journal International, vol. 1, pp 19-20

[6] Burkill, H. M. 1994. The useful plants of west tropical Africa. Royal Botanic Garden, Kew. Vol. 2: 88- 91.

[7] Ekpo M. A. and Etim P. C. 2009. Antimicrobial activity of ethanolic and aqueous extracts of Sida acuta on microorganisms from skin infection. J. Med. Plants Res., 3 (2009), pp. 621-624.

[8] Caceres A, Giron L. M., A. M. Martinez M. A. 1987. Diuretic activity of plants used for the treatment of urinary ailments in Guatemala. J. Ethnopharmacol., 19, pp. 233-245.

[9] Noor, E. A. 2005. Corrosion Science, 47: 33.

[10] Orubite-Okorosaye K and Oforka, N. C. 2004. Corrosion Inhibition of Zinc on $\mathrm{HCl}$ using Nypa fruticans Wurmb Extract and 1,5 Diphenyl Carbazone Journal of Applied Science and Environs Mgt., 8(1): 56.

[11] Dawodu F. A. and Sodiya 2015 E. F. Corrosion inhibitory characteristics of Jatropha curcas on Zinc alloy in $1.5 \mathrm{M} \mathrm{HCl}$ solution. International Journal of current research Vol 7, issue 09, pp $20524-30530$.

[12] Mathur, P. B. and Vasudevan T. 1982. Reactions Rate studies for the corrosion of metals in acid-I Iron in mineral acids Corrosion. NACE. 38, 3: 171-178.

[13] Noor E. A. and Al-Moubaraki A. H. 2008. Corrosion behavior of mild steel in Hydrochloric acid solutions. Int. J. Electrochem Sci, 3, 806-818.

[14] Ajayi, O. O., Omotosho, O. A., Ajanaku, K. O. and Olawore, B. O. 2011. Degradation of aluminium alloy in $2.0 \mathrm{M} \mathrm{HCl}$ in the presence of Chromolaena Odorata, J Eng. Applied Sci 6(1): $10-17$.

[15] Raimi, Monsurat M., Oyekanmi, Adeyinka M., And Adegoke, Bosede M. 2014. Proximate, Phytochemical and Micronutrient Composition of Sida acuta IOSR Journal of Applied Chemistry (IOSR-JAC) e-ISSN: 2278-5736. Volume 7, Issue 2 Ver. I. www.iosrjournals.org 93 | Page.

[16] Harry-Aso, Joy L. and Eno-Obong O. S. 2014 Comparative Study of the Phytochemical Properties of Jatropha curcas and Azadirachta indica Plant Extracts Journal of Poisonous and Medicinal Plants Research Vol. 2(2), pp. 020-024. ISSN 23158834@ 2014 Apex Journal International. 